\title{
Herbivore species identity and composition affect soil enzymatic activity through altered plant composition in a coastal tallgrass prairie
}

\author{
Chelse Prather a, b, *, Michael S. Strickland ${ }^{\text {c, d }}$, Angela Laws ${ }^{\text {b, e }}$, David Branson ${ }^{\mathrm{f}}$ \\ a Department of Biology, University of Dayton, 300 College Park, Dayton, OH, 45469-2320, United States \\ b Department of Biology and Biochemistry, University of Houston, Houston, TX, United States

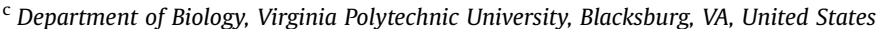 \\ ${ }^{\mathrm{d}}$ Department of Soil and Water Resources, University of Idaho, Moscow, ID, United States \\ e Department of Biology, Kansas State University, Manhattan, KS, United States \\ ${ }^{\mathrm{f}}$ United States Department of Agriculture, Agricultural Research Service, Sidney, MT, United States
}

\section{A R T I C L E I N F O}

\section{Article history:}

Received 5 October 2016

Received in revised form

16 May 2017

Accepted 16 May 2017

Available online 30 May 2017

\section{Keywords:}

Orthoptera

Acid phosphatase

$\beta$-1,4-Glucosidase

Herbivory

Carbon cycling

Phosphorus cycling

\begin{abstract}
A B S T R A C T
Although single herbivore species are known to affect soil microbial communities, the effects of herbivore species identity and community composition on soil microbes and their functioning are unknown. We tested the effects of single orthopteran species and species combinations on soil enzymatic activity with an enclosure experiment in a coastal tallgrass prairie. Species effects on soil enzymatic activity were non-additive: one particular mixed feeding species (M. femurrubrum) resulted in $65 \%$ higher BG enzyme activity and $35 \%$ higher total hydrolytic enzyme activity, whereas certain combinations containing this species had little to no effects. These results suggest that critical species or combinations of species that strongly affect plant functional composition may also have strong effects on soil enzymatic functioning and nutrient limitation.
\end{abstract}

๑) 2017 Elsevier Ltd. All rights reserved.
Herbivores can have strong positive (Belovsky and Slade, 2000) and negative effects (Millett and Edmondson, 2015) on ecosystem processes, depending on nutrient availability, feeding preferences, and other species-specific attributes (Ritchie et al., 1998; Bardgett and Wardle, 2010). Herbivores may influence primary production (Dyer, 1993; Belovsky and Slade, 2000, 2002; de Mazancourt and Loreau, 2000; La Pierre et al., 2015), nutrient cycling (Lovett and Ruesink, 1995; Belovsky and Slade, 2000, 2002; Frost and Hunter, 2004; Fonte and Schowalter, 2005; Metcalfe et al., 2015), and decomposition (Wardle et al., 2002). Their cascading effects on ecosystem functioning likely occur when their feeding alters the quantity or quality of plant material and/or soluble organic material (e.g., frass or greenfall from messy feeding) entering the soil thereby altering microbial communities (Holland, 1995; Classen et al., 2007). Researchers examining how herbivores affect soil functioning typically manipulate only one species, and few have

\footnotetext{
* Corresponding author. Current: Department of Biology, University of Dayton, 300 College Park, Dayton, OH, 45469-2320, United States.

E-mail address: chelse.prather@gmail.com (C. Prather).
}

measured how insect herbivores affect microbial communities (Yang and Gratton, 2014), and thus the roles that herbivore species identity and composition play in soil microbial functioning is unknown (Bardgett and Wardle, 2003).

Competitive interactions between coexisting herbivore species often cause shifts in species' diets and behavior, and these interactions may result in very different outcomes on soil functioning than any one species alone (Bardgett and Wardle, 2003). Even if species interactions do not alter behaviors, the presence of competitors can result in a decrease in herbivore populations, diluting species-specific effects seen with one species alone. Here, we examined how species identity and community composition of ubiquitous grassland herbivores affect soil microbial enzyme activity and stoichiometry. We predicted that species would have differential effects on soil enzymatic functioning because of species-specific feeding preferences, and that combinations of species would exhibit non-additive effects on soil enzymatic functioning.

We varied orthopteran (i.e. grasshoppers and katydids) community composition in a coastal tallgrass prairie (University of Houston's Coastal Center, La Marque, Texas, USA; $29^{\circ} 23^{\prime} \mathrm{N}$, 
Table 1

Orthopteran species used in this study. The top 4 species were focal species used in single species treatments, and all combination treatments; the bottom 4 species were only used in the 8 species combination (shown in Table 2).

\begin{tabular}{lll}
\hline Species & Family & Feeding guild \\
\hline Conocephalus strictus & Tettigonidae & Grass-feeder (occasionally feeds on other insects) \\
Melanoplus femurrubrum & Acrididae & Mixed-feeder \\
Orchelimum vulgare & Tettigonidae & Mixed-feeder (occasionally feeds on other insects) \\
Orphulella speciosa & Acrididae & Grass-feeder \\
\hline Hesperotettix speciosa & Acrididae & Forb feeder \\
Chortophaga austrailor & Acrididae & Grass-feeder \\
Melanoplus bispinosus & Acrididae & Mixed-feeder \\
Arphia simplex & Acrididae & Grass-feeder \\
\hline
\end{tabular}

Table 2

Experimental design: all treatment combinations that were sampled in this experiment are shown.

\begin{tabular}{|c|c|c|}
\hline Treatment & Species & $\mathrm{n}$ \\
\hline \multirow[t]{4}{*}{1 species } & C. strictus (10 individuals) & 6 \\
\hline & M. femurrubrum (12 individuals) & 6 \\
\hline & O. vulgare (8 individuals) & 6 \\
\hline & O. speciosa (12 individuals) & 6 \\
\hline 4 species & C. strictus (3), M. femurrubrum (3), O. vulgare (2), O. speciosa (3) & 6 \\
\hline \multirow[t]{2}{*}{8 species } & C. strictus (1), M. femurrubrum (1), O. vulgare (1), O. speciosa (1), H. speciosa (1), C. austrailior (1), M. bivittatus (1), A. simplex (1) & 6 \\
\hline & Total number of enclosures & 36 \\
\hline
\end{tabular}

Table 3

GLM results showing treatment effects on 6 different enzymes, total enzyme activity, relative C:P acquisition, and plant biomass. ${ }^{*}$ denotes significance at the $0.05 \alpha$ level.

\begin{tabular}{llll}
\hline Enzyme & $\mathrm{df}$ & $\mathrm{F}$ & $\mathrm{p}$ \\
\hline $\ln (\mathrm{AP})$ & 5,35 & 3.043 & $0.024^{*}$ \\
$\ln (\mathrm{NAG})$ & 5,34 & 0.567 & 0.725 \\
$\ln (\mathrm{BG})$ & 5,28 & 3.195 & $0.025^{*}$ \\
$\ln (\mathrm{CHB})$ & 5,33 & 0.691 & 0.635 \\
$\ln (\mathrm{POX})$ & 5,34 & 0.788 & 0.567 \\
$\ln (\mathrm{PER})$ & 5,35 & 2.317 & 0.068 \\
$\ln ($ Total) & 5,25 & 2.897 & $0.040^{*}$ \\
$\ln (\mathrm{BG}): \ln (\mathrm{AP})$ & 5,28 & 2.876 & $0.037^{*}$ \\
Grass biomass & 5,35 & 2.644 & $0.043^{*}$ \\
Herb biomass & 5,35 & 1.318 & 0.283 \\
Shrub biomass & 5,35 & 2.806 & $0.034^{*}$ \\
Total biomass & 5,35 & 3.409 & $0.015^{*}$ \\
\hline
\end{tabular}

$95^{\circ} 02^{\prime} \mathrm{W}$ ) with small field mesocosms (basal area: $0.25 \mathrm{~m}^{2}$, mesh size: $18 \times 14$ holes/inch ${ }^{2}$ ). Soils at these sites are Vertisols of the Lake Charles series (fine, smectitic, hyperthermic Typic Hapluderts). The plant community is dominated by graminoids with 3 species making up over $90 \%$ of plant biomass (Tridens longspicia; Paspalum plicatulum, and Andropogon gerardii), but some shrub species can become abundant (Berchemia scandens, Rubus argutus, and Myrica cerifera). Treatments represented 6 herbivore communities $(\mathrm{n}=6)$ ): 4 single species ( 2 grass feeders and 2 mixed grass and herb feeders); these 4 species combined; and an 8 species community that included 4 additional species, representing a more diverse community (Table 1 ). We stocked nymphal orthopterans (May 28th, 2012) at roughly equal biomass across treatments using the average adult biomass for each species ( $1.2 \mathrm{~g}$ dry weight orthopteran/enclosure). We censused enclosures weekly, and added individuals as needed to maintain stocking biomass. Nontarget organisms were removed throughout the experiment, which ended when most individuals were adults ( 7 weeks). All vegetation was clipped from each enclosure, sorted to species, dried and weighed. Soils were sampled from the center of each plot $(0-10 \mathrm{~cm})$ and stored at $-20^{\circ} \mathrm{C}$. We assessed hydrolytic enzyme activity (cellobiohydrolase (CBH), acid phosphatase (AP), N-acetyl$\beta$-glucosaminidase (NAG), and $\beta$-glucosidase (BG)) and ligninolytic enzymes (phenol oxidase (POX) and peroxidase (PER)) following DeForest (2009). Total hydrolytic functioning was measured as the sum of all hydrolytic enzymes, and we calculated enzyme stoichiometry (Sinsabaugh et al., 2008). Differences in enzyme activity, stoichiometry, and plant biomass were analyzed with univariate general linear models with treatment as the factor $(\alpha=0.05)$. We determined if changes in microbial enzyme activity were related to plant biomass shifts resulting from orthopteran communities using regression; such analyses that examine links between soil enzymes and plant biomass are common in the literature (e.g., Dornbush, 2007; Sanaullah et al., 2011). Because multiple non-independent measurements of plant biomass were tested, we used Bonferroni corrections for these regressions $(\alpha=0.017)$. All analyses were conducted in SYSTAT 13.

Although this experiment only took place over two months, orthopteran community composition had strong effects on soil enzymatic activity: orthopterans affected AP and BG activity, as well as total hydrolytic enzyme activity and the relative acquisition of $C: P$ (estimated by $\ln (B G): \ln (A P)$; Table 3; Fig. 1 ), but did not affect NAG, CHB, POX and PER enzyme activity ( $\mathrm{p}>0.05$ ). We propose several mechanisms by which orthopterans could affect soil functioning over this time scale. First, in laboratory feeding trials and our field experiments, we see evidence that many orthopterans are "messy feeders", potentially leading to high quality green litter inputs as other researchers do (Gandar, 1982). Certain orthopteran species and combinations had strong effects on soil enzymatic activity, and we propose that some of these effects may be occurring via changes in plant community composition. At this site, decomposition is relatively rapid since temperature and moisture levels are high, and some shrubs are evergreens and constantly shedding leaves; while the graminoids slowly shed leaves throughout the summer. Although the majority of the biomass was still alive at the time of plant harvest, rapid decomposition of senesced leaves, combined with greenfall from messy feeding or species-specific frass inputs could operate to affect soil functioning at this time scale. 


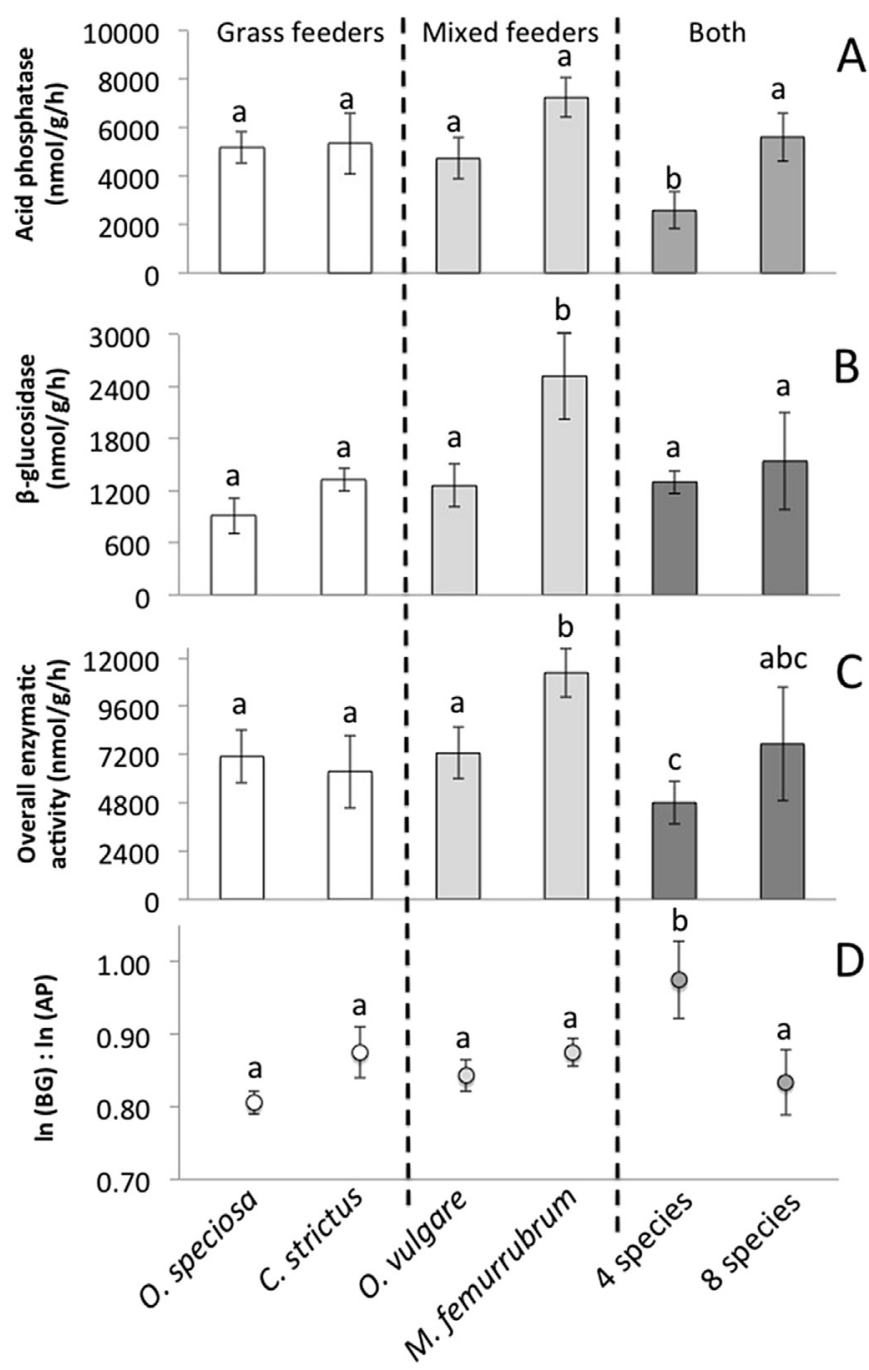

Fig. 1. Species identity and combination effects on acid phosphatase activity (A), $\beta$ glucosidase activity (B), overall enzymatic activity (C), and species identity and functional composition effects on C:P acquisition (D). Statistical tests were done on lntransformed data, but raw data are shown here. Both refers to both grass and mixed feeders present. Error bars are \pm 1 standard error.

One mixed feeder species in particular had strong influences: BG activity and total hydrolytic enzyme activity were $65 \%$ and $~ 35 \%$ greater, respectively, in soils with Melanoplus femurrubrum alone. Grass and overall plant biomass were also greater with M. femurrubrum alone (Table 3), likely because this grasshopper's feeding on shrubs releases grasses from competition. Because hydrolytic enzymes generally contribute to the degradation of cellulose (specifically, BG hydrolyzes cellobiose to glucose) more organic material entering the soil generally leads to greater hydrolytic enzyme activity, including higher BG activity (Sinsabaugh et al., 2008). Thus, higher BG and total hydrolytic enzyme activity would be expected with greater grass biomass rich in cellulose and greater plant biomass overall (i.e., greater biomass due to M. femurrubrum's feeding on forbs and shrubs would lead to a greater need to breakdown this organic material). Also, because aboveground biomass may correlate with belowground biomass, more rhizodeposition may potentially be stimulating soil communities. Additionally, total hydrolytic enzyme activity was positively related to total plant biomass across all treatments (Table 4, Fig. 2). Effects of mixed feeders were limited to M. femurrubrum: the other species of mixed feeder (Orchelimum vulgare) did not affect enzymatic activity. This finding suggests that, like mixed herbivore communities in other ecosystems, particular species can have marked effects on ecosystem function (Rasher et al., 2013).

Specific mixed communities had unexpected, non-additive effects on enzyme activity. The 4 species community was the only community that affected AP activity (which releases phosphate in soils by hydrolyzing phosphomonoesters, indicating soil P-limitation; Turner et al., 2002; Toor et al., 2003) or C:P acquisition: AP activity was $\sim 50 \%$ lower than the other treatments, and the relative acquisition of C:P was $11 \%$ higher than any single species treatment. Additionally, total hydrolytic enzymatic activity was 37\% lower compared to the single species treatments. This combination contained a potential predator, $O$. vulgare, which occasionally feeds on other insects and has large enough mandibles to capture smaller orthopterans, a phenomenon we witnessed on two occasions in this experiment. Under predation, orthopterans may alter feeding rates and preferences (Schmitz and Suttle, 2001; Hawlena et al., 2012), behavior (Schmitz et al., 1997) and thus overall stress experienced by the plants (Hartvigsen et al., 1995), which is what may have occurred here. This 4-species community resulted in lower woody plant biomass (particularly of Berchemia scandens, Rubus argutus, and Myrica cerifera), and lower plant biomass overall compared to treatments with only grass feeders present. While soil enzyme activity responded to the 4-species community, total enzyme activity in the 8 species treatment was intermediate to the other treatments, perhaps indicating the additional 4 species may offset the negative non-additive effects of the 4 species combination. This finding points to the need for future research on a wider range of comparisons including 2 species combinations.

Our study is the first to demonstrate that herbivore species identity and community composition affect soil microbial enzyme activity. We predict that herbivore species or combinations that exert control over plant functional composition, such as those decreasing woody vegetation in grasslands, will most strongly affect soil enzymatic activity through their alterations to nutrient cycling and limitation of soil microbes. We hypothesize that the effects of species competition are context dependent: for instance, we would expect that single species communities of M. femurrubrum or the 4 species community may influence soil functioning less in places with few woody species because of weaker control over plant functional composition. While this hypothesis is straightforward, it is also untested and we propose that a rigorous test of the idea that mixed feeding species have greater effects in grasslands with more woody species present is important. With the current biodiversity crisis, these results suggest a pressing need for better understanding how herbivore species and their composition affect soil microbial communities and their functioning. Alterations to aboveground herbivore communities, particularly changes in a single critical species, may induce cascading effects on belowground functioning.

Table 4

Regression results for relationships between enzymes that were significantly affected by orthopteran treatments. $\alpha$ was set at 0.017 according to Bonferroni corrections for multiple regression tests completed per enzyme.

\begin{tabular}{|c|c|c|c|c|c|c|c|}
\hline \multirow[t]{2}{*}{ Enzyme } & \multirow[t]{2}{*}{$\mathrm{n}$} & \multicolumn{2}{|c|}{$\begin{array}{l}\text { Shrub } \\
\text { biomass }\end{array}$} & \multicolumn{2}{|c|}{ Grass biomass } & \multicolumn{2}{|c|}{ Total biomass } \\
\hline & & $\mathrm{p}$ & $\mathrm{R}^{2}$ & $\mathrm{p}$ & $\mathrm{R}^{2}$ & $\mathrm{p}$ & $\mathrm{R}^{2}$ \\
\hline $\ln (\mathrm{AP})$ & 36 & 0.12 & 0.07 & $0.01^{*}$ & 0.16 & $0.007^{* *}$ & 0.20 \\
\hline $\ln (\mathrm{BG})$ & 29 & 0.27 & 0.05 & 0.05 & 0.14 & 0.14 & 0.08 \\
\hline $\ln$ (Total) & 26 & 0.24 & 0.06 & $0.001^{* *}$ & 0.36 & $0.001^{* *}$ & 0.37 \\
\hline $\ln (\mathrm{BG}): \ln (\mathrm{AP})$ & 29 & $0.01^{*}$ & 0.19 & 0.31 & 0.04 & 0.14 & 0.08 \\
\hline
\end{tabular}



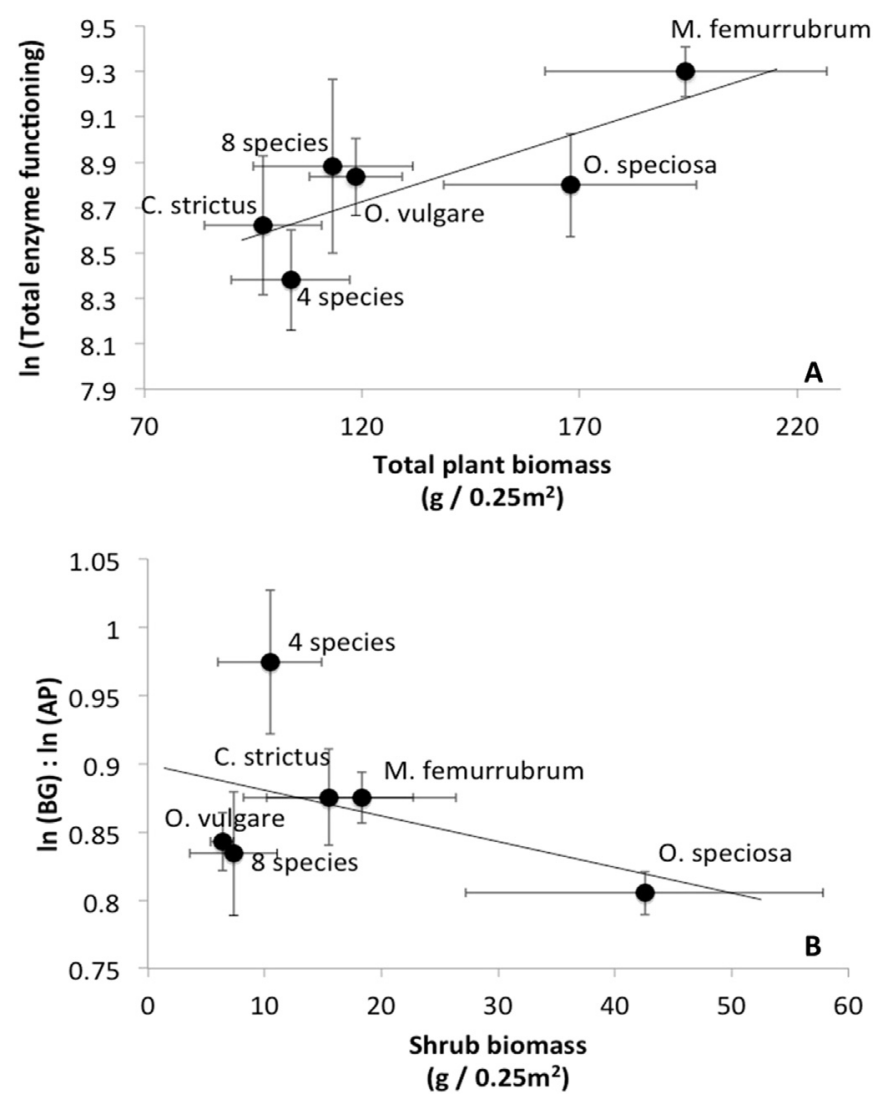

Fig. 2. Total enzyme activity as indicated by $\ln$ (sum of AP, NAG, BG and CHB) in relation to total plant biomass $(A)$ and $C: P$ acquisition as indicated by the ratio of $\ln$ $(B G): \ln (A P)$ in relation to shrub biomass (B). Error bars are \pm 1 standard error.

\section{Acknowledgments}

We thank: University of Houston's Coastal Center (salary for Prather); A. Huynh for field assistance; S. Pennings, A. Joern, and J. Jonas for input on experimental design; and A. Joern for the use of mesh enclosures. This research was partially funded by a United States Department of Agriculture AFRI Competitive Grant to Laws, Prather, Branson, and Strickland (\#2016-67014-25257).

\section{References}

Bardgett, R.D., Wardle, D.A., 2003. Herbivore-mediated linkages between aboveground and belowground communities. Ecology 84, 2258-2268.

Bardgett, R.D., Wardle, D.A., 2010. Aboveground-belowground Linkages. Oxford University Press, New York.

Belovsky, G.E., Slade, J.B., 2000. Insect herbivory accelerates nutrient cycling and increases plant production. Proceedings of the National Academy of Sciences of the United States of America 97, 14412-14417.
Belovsky, G.E., Slade, J.B., 2002. An ecosystem perspective on grasshopper control: possible advantages to no treatment. Journal of Orthoptera Research 11, 29-35.

Classen, A.T., Overby, S.T., Hart, S.C., Koch, G.W., Whitham, T.G., 2007. Season mediates herbivore effects on litter and soil microbial abundance and activity in a semi-arid woodland. Plant Soil 295, 217-227.

DeForest, J.L., 2009. The influence of time, storage temperature, and substrate age on potential soil enzyme activity in acidic forest soils using MUB-linked substrates and L-DOPA. Soil Biology and Biochemistry 41, 1180-1186.

de Mazancourt, C., Loreau, M., 2000. Effect of herbivory and plant species replacement on primary production. American Naturalist 155, 735-754.

Dornbush, M.E., 2007. Grasses, litter, and their interaction affect microbial biomass and soil enzyme activity. Soil Biology and Biochemistry 39, 2241-2249.

Dyer, M.I., 1993. Herbivory and its consequences. Ecological Applications 3, 10-16.

Fonte, S.J., Schowalter, T.D., 2005. The influence of a neotropical herbivore (Lamponius portoricensis) on nutrient cycling and soil processes. Oecologia 146 423-431.

Frost, C.J., Hunter, M.D., 2004. Insect canopy herbivory and frass deposition affect soil nutrient dynamics and export in oak mesocosms. Ecology 85, 3335-3347.

Gandar, M.V., 1982. The dynamics and trophic ecology of grasshoppers (Acridoidea) in a South African savanna. Oecologia 54, 370-378.

Hartvigsen, G., Wait, D.A., Coleman, J.S., 1995. Tri-trophic interactions influenced by resource availability: predator effects on plant performance depend on plant resources, Oikos 74, 463-468.

Hawlena, D., Strickland, M.S., Bradford, M.A., Schmitz, O.J., 2012. Fear of predation slows plant-litter decomposition. Science 336, 1434-1438.

Holland, J.N., 1995. Effects of aboveground herbivory on soil microbial biomass in convential and no-tillage agroecosystems. Applied Soil Ecology 2, 275-279.

La Pierre, K.J., Joern, A., Smith, M.D., 2015. Invertebrate, not small vertebrate, herbivory interacts with nutrient availability to impact tallgrass prairie community composition and forb biomass. Oikos 124, 842-850.

Lovett, G.M., Ruesink, A.E., 1995. Carbon and nitrogen mineralization from decomposing gypsy moth frass. Oecologia 104, 133-138.

Metcalfe, D.B., Crutsinger, G.M., Kumordzi, B.B., Wardle, D.A., 2015. Nutrient fluxes from insect herbivory increase during ecosystem retrogression in boreal forest. Ecology 97, 124-132.

Millett, J., Edmondson, S., 2015. The impact of 36 years of grazing management on soil nitrogen $(\mathrm{N})$ supply rate and Salix repens $\mathrm{N}$ status and internal cycling in dune slacks. Plant and Soil 396, 411-420.

Rasher, D.B., Hoey, A.S., Hay, M.E., 2013. Consumer diversity interacts with prey defenses to drive ecosystem function. Ecology 94, 1347-1358.

Ritchie, M.E., Tilman, D., Knops, J.M., 1998. Herbivore effects on plant and nitrogen dynamics in oak savanna. Ecology 79, 165-177.

Sanaullah, M., Blagodatskaya, E., Chabbi, A., Rumpel, C., Kuzyakov, Y., 2011. Drought effects on microbial biomass and enzyme activities in the rhizosphere of grasses depend on plant community composition. Applied Soil Ecology 48, 38-44.

Schmitz, O.J., Suttle, K.B., 2001. Effects of top predator species on direct and indirect interactions in a food web. Ecology 82, 2072-2081.

Schmitz, O.J., Beckerman, A.P., O'Brien, K.M., 1997. Behaviorally mediated trophic cascades: the effects of predation risk on food web interactions. Ecology 78 , 1388-1399.

Sinsabaugh, R.L., Lauber, C.L., Weintraub, M.N., Ahmed, B., Allison, S.D., Crenshaw, C.L., Contosta, A.R., Cusack, D., Frey, S., Gallo, M.E., Gartner, T.B., Hobbie, S.E., Holland, K., Keeler, B.L., Powers, J.S., Stursova, M., TakacsVesbach, C., Waldrop, M., Wallenstein, M., Zak, D.R., Zeglin, L.H., 2008. Stoichiometry of soil enzyme activity at global scale. Ecology Letters 11, 1252-1264.

Toor, G.S., Condron, L.M., Di, H.J., Cameron, K.C., Cade- Menum, B.J., 2003. Characterization of organic phosphorus in leachate from a grassland soil. Soil Biology and Biochemistry. 35, 1317-1323.

Turner, B.L., McKelvie, I.D., Haygarth, P.M., 2002. Characterisation of water extractable soil organic phosphorus by phosphatase hydrolysis. Soil Biology and Biochemistry 34, 27-35.

Wardle, D.A., Bonner, K.I., Barker, G.M., 2002. Linkages between plant litte decomposition, litter quality, and vegetation responses to herbivores. Functional Ecology 16, 585-595.

Yang, L.H., Gratton, C., 2014. Insects as drivers of ecosystem processes. Current Opinion in Insect Science 2, 26-32. 